"The Executive, being determined to omit no effort or spare no expense which might redound to the honor of the Nation and to the advantage of studious youth, has created an Anatomia-pathologic Museum, with the double purpose of furnishing a new and efficient element of instruction to the school of medicine, and also for the purpose of appreciating worthily the scientific labors that are to be presented to the second Pan-American Medical Congress when it meets in this Capital in 1897."

\title{
CORRESPONDENCE.
}

\section{" Audi Alteram Partem."}

Sax Fraxcisco, Cait., May 22, 1895.

To the Ellitor:-[Our esteemed correspondent, whose letter pronouncing the collective investigation of the antitoxin treatment of diphtheria impossible of execution was published in the Jourxal of May 11, takes exception to the summary fashion in which his first communication was treated, and furnishes the following argument, in support of his belief that the results of such investigation must be valueless.]

I feel perfectly safe in saying that, in the present light of science, no living person can make a positive differential diagnosis between typical Bretannean diphtheria and allied affections-and for the following reasons:

1. A scinizomycete answering (Löfller's) description has been found in less than 50 per cent. of cases of clinical diphtheria-and then never alone, always together with other forms, such as streptococci, staphylococci, pneumococci, bact. coli communis and micrococcus prodigiosus (See Hausemann, Benda, Ritter, Körte and others. Proceedings Berlin Medical Society, Nov. 28, Dec. 7, 12, 1894; also report of New York Board of Health on the bacteriologic investigation of 6,511 cases of clinical diphtheria between May 4, 1893, and May 4, 1894).

2. This virulent bacillus has been found in the mouth and throat of perfectly healthy children, and nurses in diphtheria wards. Also in connection with cases of rhinitis fibrinosa running the same clinical course as other cases in which it was absent (Benda, Liebreich, Hausemann, Ritter, Unger and others. Proceedings Berlin Medical Society, Nov. 28, Dec. $7,12,189 t)$.

3. The disease produced in the lower animals by injections of so-called pure cultures of Löffler's bacillus diphthericus, differs radically from typical Bretannean diphtheria in human beings (Hausemann, Ritter, Benda, Scheineman, Unger, Scholz and others. Proceedings Berlin Medical Society, 28 , Dec. $7,12,1894)$.

4. Ritter found bacilli absent in a case of typical Bretannean diphtheria.

5. Polymorphism of schizomycetes, such as the bact. coli communis and others common to the alimentary canal of human beings and the lower animals-and constantly found within the internal organs of diseased organic forms before and immediately after death-render a scientitic bacteriologic diagnosis impossible. (See reports on the following poison epidemics: 1, at Frankenhausen, investigated by Professor Gartner; 2, at Rörsdorf, investigated by Gaffky and Paak; 3 , at Moorsule, investigated by Van Ermengen; 4 , at Cotta, investigated by Nulsen, Zohne and Gartner; 5 , at Ganstad Insane Asylum, investigated by Peter F. Holst. Also Wurtz and Hermann, Macaigne, Welch of Baltimore, Lubarsale. Tavel, Roux, Escherick, Fraenkel, Dunbar, Rodet, Stocklin, Cohn, Lankester, Billroth and others. Duclaux

writes in l'Annules de l'Institute, Pasteur, 1891, page 350): "Chagne annè de travail fond ensemlle des espices, qu'on croyait distinctes et en sipare d'autres, qu'on croyat identique."

(Each year's labor removes us farther from the hope of distinguishing and separating from one another "forms" thought to have been identified.)

Serum-therapy is entirely "empirical," inasmuch as leading investigators in this field differ widely in regard to the modus operandi of "immunity," said to occur in connection with organic forms having passed through so-called "infectious diseases" and it can not be said that any of these theories, which may be enumerated as follows, has stood the test of severe adverse criticism: 1 , Pasteur's exhaustion theory ; 2, Chavau's retention theory; 3, Metschnikoff's phagocytosis theory; 4, Buchner and Hankins alexin theory; 5 , Koch-Behring antitoxin or chemic theory. All of these theories are stubbornly adhered to by their respective originators.

Antitoxin serum-therapy is essentially the outcome of the violent opposition offered by Koch and his disciples to Metschnikoff's phagocytosis teachings-chemic or humeropathologic processes versus Virchow's intra-cellular processes-and while many things point toward the latter, still there exist no scientific data corroborative of any theory, and any therapeutic method based thereon is unscientificempirical as it were. For an exhaustive treatise on the various theories, experiments and data leading up to the introduction of antitoxin blood serum into human therapeutics, see my paper, "The Status Presens of Antitoxin Blood Serum," read before the State Medical Society of California April 16, 1895.

For reasons too obvious to mention, antitoxin diphtheria serum has been more thoroughly tested in Berlin where it originated than elsewhere, and inasmuch as leading unbiased Berlin physicians have tested its merits during the past five years, and expressed their views thereon professionally, we are in a position to judge correctly of the matter. In the Berlin Medical Society, Nov. 28 and Dec. 7 and 12, 1894, Hausemann, Ritter, Benda, Unger, Scholz, Liebreich, Oppenheim, Hahn, Meyer, Gottstein and others went on record as saying that, "antitoxin diphtheria serum did neither render immune nor cure diphtheria as elaimed by Behring, but that it complicated said disease by giving rise to serious inflammations of important functionating organs such as: the liver, spleen, heart, kidneys, nervous system and skin-the direct result of chemic decomposition of the blood,"

Nor does the following mortality statistics, appertaining to Berlin, compiled by Gottstein from the official death register of the city, show the serum-therapy up in a very favorable light when studied attentively and without bias:

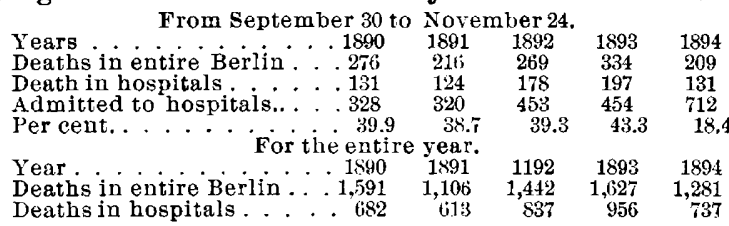

For reasons too obvious to mention, hospital mortality is much less than that of private practice-hence we can readily understand why the mortality from Sept. 30 to Nov. 24,1894 , appears to be reduced to half of that of a corresponding period in 1891, because for some reason, probable panic attendant upon serum notoriety, 712 patients were admitted to the hospitals in 1894 against 320 in 1891. To what extent these 712 hospital cases have been manipulated by the friends of the serum can best be seen by referring to the last columns of these statistics which show: that the mortality from diphtheria for entire Berlin during 1894 up to November 24 far exceeds that of the entire year of 
1891-in spite of the fact that over 1,000 children were treated by the serum method in the hospitals, beside numerous cases in private practice. Adding the number of deaths that occurred between November 24 and January 1, the mortality of Berlin from diphtheria in 1894 exceeded that of the year 1891 by about 600 , or over 25 per cent.

Rumpf, of Hamburg, states that better results are obtained in the hospitals there by other methods.

Virchow and Baginsky have expressed themselves in favor of the serum-therapy, but inasmuch as the opinion of the former is based upon certain results said to have been obtained by his assistants during a few weeks in the summer of 1894 , while he was absent on his vacation-and inasmuch as the latter entirely ignores and defies mortality statistics-their opinions upon this subject can be of little or no value. (See Proc. Berlin Medical Society, Nov. 28, Dec. 7, 12, 1894.)

I will exclude all data coming from Behring, Aronson and others personally interested in the manufacture and sale of antitoxin serum. As a rule, medical men in Europe are very conservative regarding this new therapy-as they have not yet recovered from the humiliating effects of the "tuberculin swindle," which originated in the same quarters.

So far, nothing has appeared in the American medical press which would indicate that medical men in this country are familiar with the cardinal principles underlying this subject-and I would advise them to "look before they leap," as perhaps neither "they" nor the "American public" are ready to accept these principles when fully understood.

These principles were exposed by Binz in 1883 at the BudaPesth Congress for Internal Medicine, when he said: "Our future therapeutic efforts in infectious diseases must be toward 'Den lebenden organisms zu entgiften." (To poison the organism, as it were.)

I take issue with Binz and his followers on this doctrine and I believe that the majority of the American medical profession will continue in the future as they have done in the past-to eliminate the contagium at the bedside. "Den lebenden organisms nicht zu entgiften-wollen." Respectfully. Chas. G. Kuhl.Man, M.D.

\section{Answer to Dr. Rogers.}

New YoRk, June 10, 1895.

To the Editor:-Dr. Rogers' attack upon Koch's demonstration of the causation of cholera, in the Journal of June 8 , is rather amusing to the medical man of to-day. While believing that he will receive answers more able than mine, I take the liberty of calling his attention to a few errors in his statement.

In the first place, Koch did not "fancy" that the comma bacillus was the cause of cholera; it had to be present in every case of cholera, it had to be capable of cultivation in artificial media in pure culture, and it had to produce the disease whenever inoculated, before he was willing to identify it as the cause. Unfortunately, the inoculation experiments do not depend alone upon results obtained in the lower animals, for several bacteriologists have themselves been infected while working with this organism.

In the second place, while comma-shaped organisms are universal, as the Doctor states, the comma bacillus of Koch is neither universal nor harmless. If the shape of microorganisms alone were sufficient to differentiate them, what a simple easy study would be the science of bacteriology! Dr. Koch has never asserted, to my knowledge, that the cholera bacillus is frequently present in water from all sources, although any up-to-date physician knows that curved bacilli are frequently present. All cholera germs are curved bacilli, but all curved bacilli are not cholera germs.

The experiments of Drs. Pettenkofer and Emmerich, as alluded to in the letter, prove nothing, for the following (and other) reasons:
1. Koch and many other observers have shown that acids readily kill this organism; we can easily understand, therefore, how the healthy acid gastric juice of the two physicians protected them from infection. Drinking cholera broth does not necessarily imply infection; it only makes infection possible. The liquid stools mentioned can be produced by toxins isolated from old cultures, without any bacilli being present.

2. Organisms grown on artificial media for many generations are very apt to lose their virulence, even though they may have been very virulent in the first few cultures.

In conclusion, I would hardly advise Dr. Rogers to repeat the experiments of Pettenkofer and Emmerich, as such a communication as he has given us, in defiance of modern scientific research, might indicate that his gastric juice had alkalin tendencies! Yours respectfully, Walter G. Hudson, M.D.

\section{A Card from Secretary Atkinson.}

Philadelphia, June 4, 1895.

To the Editor:-Your explanation of the inability to send the Jovrsal to the new members does me great injustice. As I wrote you, not any of the credentials nor papers of the Registration Committee have yet reached me. All were sent directly to Dr. Newman, our Treasurer. Had I had the list or my own private index, made especially to prevent this, I would have had my share done at once. For this reason, I ask you to do me the justice to announce in the JourNAL the fact that all the papers were sent at once to Chicago. I am getting letters on this subject constantly, and it is important that I should be set right before the profession. Please do me this favor at once.

$$
\text { Yours very truly, }
$$

Wm. B. Atikinson.

\section{Literature on the Dual Brain.}

Str. Lours, June 4, 1895.

To the Editor:-I have read with interest your editorial on the "Dual Brain," in a recent number of the Jourval. Please inform me how I can procure Dr. Bruce's article on this subject, also the writings of Holland and Wigand, and Brown-Séquard.

Fayette C. Ewing, M.D.

Axswer:-Dr. Wigand, "Duality of Mind," Lancet, 1844 ; Sir Henry Holland, "Chapters on Physiology of Mind," 1852; Brown-Séquard, Toner Lecture, 1877 ; L. C. Bruce's article in Brain, Spring No., 1895.

\section{Exact Address of Association Treasurer.}

Coronado, Cal., June 1, 1895.

To the Editor:-Will you please insert in our Journas the exact place of residence of the Treasurer of the Association, that members may know just where to send dues.

F. W. Tond, M.D.

Axswer:-Henry P. Newman, M.D., 36 Washington Street, Chicago, Ill.

\section{SOCIETY NEWS.}

American Academy of Railway Surgeons, Meeting of the Publication Committee.-Pursuant to the call of the President, Dr. C. K. Cole, Helena, Mont., Drs. C. B. Kibler, Corry, Pa ; W. J. Galbraith, Omaha, Neb.; R. Harvey Reed, Columbus, Ohio; C. M. Daniels, Buffalo, N. Y., and Webb J. Kelly, Galion, Ohio, met June 1, at Galion, Ohio, to arrange the preliminary work for the coming session of the American Academy of Railway Surgeons. After considerable discussion, the date of the meeting was set for September 25,26, and 27. This was thought advisable on account of the previous date conflicting with those of other prominent associations; and 